\title{
Barrier to Reproductive Health Services in Adolescents in Sukoharjo, Central Java
}

\author{
Maryatun, Indarwati, Endang Sri Wahyuni, Hermawati
}

Study Program of Nursing, School of Health Sciences Aisyiyah, Surakarta

\section{ABSTRACT}

Background: Adolescent reproductive health information and services (KRR) are right, teenagers are helped to recognize themselves and $\mathrm{m}$ atters relating to reproductive health. By having correct information, adolescents can equip themselves with behaviors and skills that can protect themselves from various reproductive health risks. This study aimed to analyze the factors that influence barriers to adolescent reproductive health services in schools.

Subjects and Method: This was a cross sectional study was conducted at high schools in Sukoharjo, Central Java, from April to May 2018. The sample was 281 students selected by purposive sampling. The dependent variable is barriers to adolescent reproductive health services. The independent variables are attitude, information, distance of service, ability of service personnel, and utilization of health service facilities. Data were analyzed using Chi square.

Results: The use of reproductive health services increased with knowledge of reproductive health $(\mathrm{OR}=4.06 ; 95 \% \mathrm{CI}=1.8$ to $9.2 ; \mathrm{p}<0.001)$, posi- tive attitude towards reproductive health $(\mathrm{OR}=$ 2.43 ; $95 \% \mathrm{CI}=1.2$ to $5.1 ; \mathrm{p}=0.016)$, get information on $\mathrm{KRR}$ services $(\mathrm{OR}=2.15 ; 95 \% \mathrm{CI}=1.05$ to $4.4 ; \mathrm{p}=0.034$ ), easy access to KRR services $(\mathrm{OR}=2.2 ; 95 \% \mathrm{CI}=1.5$ to $4.6 ; \mathrm{p}=0.033)$, the ability of officers in provide services $(\mathrm{OR}=2.47 ; 95 \%$ $\mathrm{CI}=1.2$ to $5.2 ; \mathrm{p}=0.014$ ), and utilization of health service facilities $(\mathrm{OR}=1.5 ; 95 \% \mathrm{CI}=0.78$ to 3.1 ; $\mathrm{p}=0.21$ ).

Conclusion: Low service barriers are influenced by knowledge of reproductive health, positive attitudes towards reproductive health, obtaining information on KRR services, easy access to KRR services, the ability of officers to provide services, and utilization of health service facilities.

Keywords: service barriers, adolescent reproductive health
Correspondence:
Maryatun. Study Program of Nursing, School of Health Sciences Aisyiyah, Surakarta. Email: tun- maryatun76@gmail.com.

Cite this as:

Maryatun, Indarwati, Wahyuni ES, Hermawati (2020). Barrier to Reproductive Health Services in Adolescents in Sukoharjo, Central Java. J Health Policy Manage. 5(1): 85-91. https://doi.org/10.26911/thejhpm.2020.05.01.08 cC (†) (9) Journal of Health Policy and Management is licensed under a Creative Commons Journal of Health Policy and Management is licensed under a Creati
Attribution-Non Commercial-Share Alike 4.0 International License.

BACKGROUND

Reproductive health services are an important component that must be improved by global health, because adolescents often lack basic information about reproductive health. Adolescents need reproductive health services, but few adolescents use these services, the cause of obstacles in receiving sexual and reproductive health services is due to lack of access to the services they need and negative perceptions of reproductive health service centers (Blanco, 2016).
Information on reproductive health is currently considered unfavorable for adolescents. The problem faced is that the utilization of the Information Center for Adolescent Reproductive Health (PIK-KRR) in schools is still lacking and there are not many puskesmas conducting adolescent health activities (Ministry of Health, 2015). Many factors cause the low utilization of health services by adolescents, among others, because access to services, adolescent needs, attitudes and reproductive health services provided are less 
accepted by adolescents (Chandra et al., 2015). Barriers to service in providing reproductive health information are a challenge for schools or the government today.

Government efforts in preventing against the dangers that threaten adolescents have been done through several ways, among others, by providing funding in the $\mathrm{RH}$ program through national programs or development programs carried out by the respective regions. In the high school in Sukoharjo regency, starting in 2009, coaching had been carried out in schools for both teachers and students. This activity is carried out in collaboration with the Office of Women's Empowerment and Family Planning.

High schools in accordance with the KPP and KB program are asked to organize a Information Center for Adolescent Reproductive Health Counseling (PIK KRR). However, PIK KRR activities in these schools could not be carried out as expected. Searching from observations at high schools on reproductive health services and establishing a number of high schools in Sukoharjo Regency as a place for PIK KRR shows that most PIK KRR activities cannot yet run optimally. From the counseling section, data is obtained that the problem faced is the lack of students' interest in coming to consult about reproductive health issues.

\section{SUBJECTS AND METHOD}

\section{Study Design}

This study was an observational analytic with cross-sectional design. It was conducted in Sukoharjo, Central Java, from April to June 2018.

\section{Population and Sample}

The population used in the study was high school teenagers in Sukoharjo, Central Java, who have had a PIK KRR program since 2016, totaling 2,160 students. The sample was 281 high school students selected by purposive sampling.

\section{Study Variables}

The dependent variable is the use of reproductive health services. The independent variables are attitude, information, distance of service, ability of service personnel, and utilization of health service facilities.

4. Operational Definition of Variables Adolescent knowledge was some of the things that teens know about reproductive health services, that knowledge.

Attitude was supportive or non-supportive behavior towards something related to their reproductive health.

Service information was the information provided by the school during the reproductive health consultation time.

Availability of service was the school provides a comfortable place for students to conduct reproductive health consultations.

The ability of service officer was the understanding of adolescents about the attitude of officers in providing services according to the concept of youth friendly that is friendly, responsive, and friendly to the procedures that must be undertaken to obtain reproductive health services to adolescents.

Ease of service was a teenage procedure for getting services including waiting time, uncomplicated service procedures.

Availability of service facility was a school providing facilities in providing reproductive health information.

\section{Data Analysis}

The data was analysed using Chi-square.

\section{Research Ethic}

Research ethics includes informed consent, anonymity, confidentiality, and ethical clearance. Ethical clearance in this study was conducted at the Faculty of Medicine, Universitas Sebelas Maret under number: 310/UN27.6/KEPK/2018.

\section{RESULTS}

1. Univariate Analysis

Table 1 illustrates that based on knowledge 
variables, there are still $45.2 \%$ who lack knowledge about Reproductive Health, the attitude of adolescents is mostly $55.8 \%$ positive related to adolescent reproductive health services.

Based on the information variable, more than $50 \%$ have received information about adolescent reproductive health, more than $50 \%$ of adolescents find it easy to access reproductive health services in high school and $54 \%$ of adolescents assess that adolescent reproductive health care workers in high school are able to provide good services. Of the 281 adolescents in this study, 240 or $85 \%$ had never used adolescent reproductive health services in high school.

\section{Bivariate Analysis}

Table 2 shows the results of the bivariate analysis with the Chi square test on factors related to the use of Adolescent Reproductive Health services in schools.
Table 1. Characteristics of Samples (categorical data)

\begin{tabular}{lc}
\hline \multicolumn{1}{c}{ Variable } & $\begin{array}{c}\text { Frequency } \\
\text { (\%) }\end{array}$ \\
\hline Knowledge & \\
Good & $154(54.8 \%)$ \\
Poor & $127(45.2 \%)$ \\
Attitude & \\
Positive & $157(55.8 \%)$ \\
Negative & $124(44.2 \%)$ \\
Getting KRR Service & \\
Information & \\
Yes & $156(55.5 \%)$ \\
No & $125(44.5 \%)$ \\
Easy access to KRR & \\
services & \\
Easy & $163(58 \%)$ \\
Limited & $118(42 \%)$ \\
The ability of officers in & \\
providing services & \\
Good & $156(55.5 \%)$ \\
Poor & $125(44.5 \%)$ \\
Utilization of Health & \\
Services & \\
Yes & \\
No & $153(54.4 \%)$ \\
\hline
\end{tabular}

Table 2. Results of bivariate analysis of factors related to the use of Adolescent Reproductive Health services in schools

\begin{tabular}{|c|c|c|c|c|c|c|c|}
\hline \multirow{2}{*}{$\begin{array}{l}\text { Independent } \\
\text { Variable }\end{array}$} & \multicolumn{3}{|c|}{$\begin{array}{c}\text { Use of Reproductive Health } \\
\text { Services }\end{array}$} & \multirow{2}{*}{ OR } & \multicolumn{2}{|c|}{$95 \%$ CI } & \multirow{2}{*}{$\mathbf{p}$} \\
\hline & Yes & No & Total & & $\begin{array}{c}\text { Lower } \\
\text { Limit } \\
\end{array}$ & $\begin{array}{c}\text { Upper } \\
\text { Limit }\end{array}$ & \\
\hline \multicolumn{8}{|l|}{ Knowledge } \\
\hline Good & 33 (21.4\%) & $121(78.6 \%)$ & 154 (100\%) & 4.06 & 1.8 & 9.2 & $<0.001$ \\
\hline Poor & 8 (6.3\%) & $119(93.7 \%)$ & $127(100 \%)$ & & & & \\
\hline \multicolumn{8}{|l|}{ Attitude } \\
\hline Positive & $30(19.1 \%)$ & $127(80.9 \%)$ & $157(100 \%)$ & 2.43 & 1.2 & 5.1 & 0.016 \\
\hline Negative & $11(8.9 \%)$ & 113 (91.1\%) & 124 (100\%) & & & & \\
\hline \multicolumn{8}{|l|}{ Getting KRR } \\
\hline \multirow{2}{*}{\multicolumn{8}{|c|}{$\begin{array}{l}\text { Service } \\
\text { Information }\end{array}$}} \\
\hline & & & & & & & \\
\hline Yes & $29(18.9 \%)$ & $127(80.1 \%)$ & $156(100 \%)$ & 2.15 & 1.05 & 4.4 & 0.034 \\
\hline No & 12 (9.6\%) & 113 (90.4\%) & 125 (100\%) & & & & \\
\hline \multicolumn{8}{|l|}{$\begin{array}{l}\text { Easy access to } \\
\text { KRR services }\end{array}$} \\
\hline Easy & $30(18.4 \%)$ & $133(81.6 \%)$ & $163(100 \%)$ & 2.20 & 1.5 & 4.6) & 0.033 \\
\hline Limited & $11(9.3 \%)$ & $107(90.7 \%)$ & $118(100 \%)$ & & & & \\
\hline \multicolumn{8}{|l|}{$\begin{array}{l}\text { The ability of } \\
\text { officers in } \\
\text { providing } \\
\text { services }\end{array}$} \\
\hline Good & $30(19.2 \%)$ & $126(80.8 \%)$ & 156 (100\%) & 2.47 & 1.2 & 5.2 & 0.014 \\
\hline Poor & $11(8.8 \%)$ & $114(91.2 \%)$ & $125(100 \%)$ & & & & \\
\hline
\end{tabular}




\section{DISCUSSION}

1. The effect of knowledge on the use of Adolescent Reproductive Health services

Barriers to the use of reproductive health services by adolescents are also due to the low knowledge of adolescents regarding reproductive health services such as the type of service provided, place and time of service.

According to Berhane et al. (2005), adolescents have a perception that reproductive health services are provided for people who are married or for people with problems, not for teenagers in general. Based on the results of his study, $72 \%$ of adolescents said they were afraid of being known by parents or people they knew were the main barriers to utilizing reproductive health services, while $67.8 \%$ were due to feelings of shame in asking officers for reproductive health services.

Adolescent perceptions about reproductive health services are only for teenagers who have problems, besides that teens also assume that if they come to reproductive health services, they will get bad images.

\section{The effect of attitude on the use of} Adolescent Reproductive Health services

The ease of use of reproductive health services is important for adolescents. The use of reproductive health services can prevent teenagers from taking risky actions related to health, promoting healthy living habits and improving health. Observations in the field show that adolescents have not used existing reproductive health services.

Perception about wrong reproductive health services will have an impact on the attitudes and behavior of adolescents in dealing with reproductive health problems. Lack of knowledge or information about the availability of reproductive health services will get false and misleading information, causing a negative perception of adolescent reproduc- tive health services.

To avoid negative perceptions about reproductive health services, adolescents need true and appropriate information or knowledge. Agampodi (2008), examines: Adolescents perception of reproductive health care services in Sri Lanka. This study uses a qualitative method, which examines adolescent perceptions about reproductive health services.

The results of this study are adolescents who do not want to use reproductive health services because adolescents' negative perceptions of services and they do not need these services. Young women prefer to discuss their reproductive health issues with their mothers but are more often done with peers, while boys don't trust other people to talk about their reproductive health issues except with their peers. Someone will use health services if they realize that health services are needed. If adolescents realize that reproductive health services are something that teenagers need, they will take advantage of reproductive health services (Marmi, 2014).

This study is in line with the results of the Situmorang (2011) study, which states that the prevalence of adolescents who use reproductive health services, has 2.36 times greater in adolescents who have a positive attitude than in adolescents who have a negative attitude $(\mathrm{RP}=2.36 ; 95 \% \mathrm{CI}=1.16$ to $4.80 ; p=0.030$ ) shows that there is a significant relationship between adolescent attitudes with the use of reproductive health services to get KRR Service Information and Utilization of Adolescent Reproductive Health Services at Sukoharjo High School.

The teenage stage is a transition period between children and adults, almost 1 in 6 people on earth are teenagers and $85 \%$ of them live in developing countries. The period where often faces reproductive health risks, so that reproductive health services are 
needed for adolescents (Asrori, 2011). Schools are one of the centers for the delivery of logical reproductive health information. The problem faced is the use of Information Centers and Adolescent Reproductive Health Consultation (PIK-KRR) in schools is still lacking, many factors cause the low utilization of health services by adolescents, among others because of access to services, adolescent needs, attitudes and reproductive health services provided less accepted by teenagers.

Lack of understanding of sexual behavior in adolescents is very detrimental to adolescents themselves, including their families, because during this period adolescents experience important developments that are emotional, social and sexual cognitive (Soetjiningsih, 2007). Further explained the lack of understanding is caused by various factors including: customs, culture, religion and lack of information from the correct sources (Kelly et al., 2009). This lack of understanding will result in various impacts which are very detrimental to the group of adolescents and their families. For this reason, the existence of a reproductive health service center that specializes in serving youth is essential. Barriers to adolescent access to reproductive health services are influenced by social and cultural acceptance in the surrounding community.

\section{The effect of ease of access to servi- ces with the use of Adolescent Re- productive Health services}

This study is in line with study conducted by Arifah and Sharfinah (2018) which says that barriers tend to reduce student interest in accessing reproductive health services.

Ricketts and Bruce (2006) reported due to the prevalence of adolescent behavior towards risky health and knowledge of health issues involving adolescents, it was decided that schools were a logical center for delivering information. Schools are expected to be able to provide clear information about reproductive health issues, so that eventually adolescents become more familiar with accessing information from schools. Schoolbased programs are an essential approach for providing reproductive health education to young people.

Seeing the large presence of adolescents in schools, then one of the effective and efficient ways is to equip knowledge and instill healthy and responsible behavior through education in schools in the form of providing information about relevant reproductive health in school-based health services. School based programs are an essential approach to providing reproductive health education to young people.

\section{The effect of officers' abilities and use of Adolescent Reproductive Health services}

According to Russell (2005), trust is the center of a good relationship between users and health care providers that effectively encourages people to utilize health services because of the uncertainty of a patient's health condition that requires motivation and decisions from a doctor, trust facilitates communication and focus on patients who encourage community to utilize health services. Patient trust in service providers influences treatment seeking behavior.

Teenagers will choose health services that are friendly. With the friendly services of adolescents, they will feel comfortable, so the need for friendly, reproductive health services. To create friendly health services for adolescents the need for training of officers so that they have a sense of respect for privacy, instill trust in adolescents and create a comfortable service environment (Khoung and Anh, 2013). Ideally the service should increase the sense of responsibility and regular training of officers (Kurtz et al., 2005).

\section{The effect availability of facilities and use of Adolescent Reproductive Health services}


Adolescent reproductive health problems actually depend not only on the availability of health service facilities, but also on the willingness of adolescents to seek reproductive health services. Utilization of reproductive health services by adolescents is still low (Marcell et al., 2011).

The low utilization of reproductive health services by adolescents in Indonesia is partly caused by 1) incomplete health facilities available; 2) unfriendly attitude of health workers and lack of skills possessed; 3) procedures and regulations that apply are not in line with the expectations of adolescents and 4) adolescents have insufficient knowledge and information about reproductive health (WHO, 2012).

\section{AUTHOR CONTRIBUTION}

Maryatun and Indarwati were the main authors in preparing and compiling all authors needs. Endang Sri Wahyuni took over the statistical calculations. Hermawati played a role as a reviewer of the final results in this study.

\section{CONFLICT OF INTEREST}

There is no conflict of interest in this study.

FUNDING AND SPONSORSHIP

This study was funded by Surakarta Aisyiyah School of Health Sciences.

\section{ACKNOWLEDGEMENT}

We would like to show our gratitude to teenagers at schools in Sukoharjo participating the subjects in this study.

\section{REFERENCE}

Agampodi SB (2008). Adolescent's perception of reproductive health care services in Srilanka. BMC Health services, 8(98): 1472-6963

Arifah I, Sharfina MF (2018). Hambatan Akses Informasi Kesehatan Reproduksi Pada Mahasiswa Kesehatan Universitas Muhammadiyah Surakarta (Obstacles to
Access to Reproductive Health Information in Health Students of the University of Muhammadiyah Surakarta). Jurnal Kesehatan, 11(2). https://doi.org/10.23917/jurnal\%2okesehatan.v11i2.7532.

Asrori A (2011). Psikologi Remaja. Jakarta: EGC.

Berhane F, Berhane Y, Fantalun M (2005). Adolescents' Health Services Utilization Pattern and Preferences: Consultation for Reproductive Health Problems and Mental Stress are less likely. Ethiop J Health Dev, 19(1): 29-36.

Blanco DV (2016). Global Reproductive Health: Perspectives, Challenges, and Future Directions, Research Article: Global Reproductive Health Asia-Pacific Social Science, 16(1): 62-80.

Chandra-Mouli V, Svanemyr J, Amin A, Fogstad H, Say L, Girard F, Temmerman $M$ (2015). Twenty years after International Conference on Population and Development: where are we with adolescent sexual and reproductive health and rights? Journal of Adolescent Health, $56(1)$.

Kelly MP, Stewart E, Morgan A, Killoran A, Fischer A, Threlfall A, et al. (2009). A conceptual framework for public health: NICE's emerging approach. Public Health. The Royal Society for Public Health. 123(1): e14-20. http://dx.doi.org/10.1016/j.puhe.2008.10.031

Khoung MN, Anh HTH (2013). Direct and indirect effects of customer satisfaction thr ough product and service quality a study of Phu Nhuan jewelry stores in Ho Chi Minh City, Vietnam. Journal of Economics, Business and Management, 1(3): 285-290.

Kurtz S, Silverman J, Draper J (2005). Teaching and learning communication skills in medicine. $2^{\text {nd }}$ ed. Oxon: Radcliffe Publishing Ltd.

Marcell AV, Wibbelsman C, Seigel WM 
(2011). Male Adolescent Sexual and Reproductive Health Care. Pediatrics; 128: $1658-1678$.

Marmi (2014). Kesehatan Reproduksi. Yogyakarta: Pustaka pelajar.

Ministry of Health (2015). Infodatin Pusat Data Informasi Kementerian Kesehatan RI Indonesia Situasi Kesehatan Reproduksi Remaja.

Negash W, Dessalegn M, Yitayew B, Demsie M (2016). Reproductive Health Service Utilization and Associated Factors: The Case of North Shewa Zone Youth, Amhara Region, Ethiopia, the Pan African Medical Journal. 25 (2).

Ricketts SA, Bruce PG (2006). School based health centers and the decline in black teen fertility during the 1990 s in Denver, Colorado. American Journal of Public Health, 96(9): 1588-592.
Russell S (2005). Treatment-seeking behavior in urban Sri Lanka: Trusting the state, trusting private providers. Journal of Social Science \& Medicine, 61: 1396407.

Situmorang A (2011). Pelayanan Kesehatan Reproduksi Remaja Di Puskesmas: Isu dan Tantangan (Adolescent Reproductive Health Services in Puskesmas: Issues and Challenges), Jurnal Indonesian Publication Index (IPI), 6(2).

Soetjiningsih (2007). Tumbuh Kembang Remaja dan Permasalahannya (Adolescent Growth and Its Problems). Jakarta: EGC

WHO (2012). Adolescent Friendly Health Services: An Impact Model to Evaluate Their Effectiveness and Cost. Manchester, United Jakarta: CV. Sagung Seto. Kingdom: WHO. 